\title{
The Response of Class X IPA SMAN 3 Muaro Jambi Students to the Application of the Jigsaw-Type Cooperative Learning Model in Physics Learning
}

\author{
Astalini, Dwi Agus Kurniawana), Darmaji, Erika, Riko \\ Physics Education, Jambi University, J l. Lintas Sumatra Jl. Jambi - Muara Bulian No.Km. 15, \\ Mendalo Darat, Kec. Jambi Outer City, Muaro Jambi Regency, Jambi 36122, Indonesia
}

$\bowtie:{ }^{a)}$ dwiagus.k@unja.ac.id

\begin{abstract}
Generally, the learning model used in physics learning is the lecture learning model. The use of a suitable learning model can undoubtedly attract the interest and attention of students. The novelty of this research is the implementation or application of the jigsaw cooperative learning model to determine the students 'responses to the Jigsaw cooperative learning model. This study aims to describe the students' responses to the application of the jigsaw cooperative learning model in physics subjects. The method used is the mixing method (mixture). Quantitative data is obtained by collecting data in the form of a questionnaire. Qualitative data were obtained using an interview instrument sheet. The results showed that $65 \%$ (13 of 20 students) responded quite well, and $35 \%$ (7 of 20 students) responded well to applying the jigsaw cooperative learning model in physics lessons.
\end{abstract}

Keywords: cooperative models, jigsaw, physics learning

\section{INTRODUCTION}

One of the central stimulants that maintain the stability and effort of students in the learning process and ultimately contribute to their success in the educational process is motivation (Vanslambrouck et al., 2018). Experts divide motivation into two major groups, namely intrinsic motivation and extrinsic motivation, related to learning motivation and academic motivation (Dewi, Asrial, \& Hariyadi 2015). In intrinsic motivation, individuals exhibit several behaviors to achieve a sense of competence and determine their faith. Behavior that comes from inherent motivation occurs in the circumstances such as overcoming challenges and reducing dissonance or based on environmental conditions. Extrinsic motivation is created because of incentives and rewards from outside (Mustamiin 2016). For example, specific rules and regulations can lead to behavior that comes from extrinsic motivation.

Psychologists have stated that motivation should be considered in education because of its relationship to learning. They have also presented academic motivation as one of the main structures for defining this type of motivation (Dewi, Asrial, \& Hariyadi 2015). Motivation is a stimulus for students to complete a task, achieve a goal, and achieve a high level of competence in their profession. Great attention has been paid to academic motivation in studies conducted on teaching and learning worldwide. Evidence has shown that the higher motivation of students results in their more significant efforts under challenging affairs as well as their resistance in the face of obstacles, which improves their skills and promotes their scientific performance (Astuti 2015). Furthermore, academic motivation is associated with educational progress among medical students and is effective in their educational attainment. Overall, the energy needed to carry out academic tasks is generated by motivation. 
The teaching methodology is one of the strategies to create motivation and promotion of learning (Astalini, Kurniawan, \& Sumaryanti 2018). Since instructors play a crucial role in the teaching and learning process, they need to have sufficient knowledge of new teaching methods to teach appropriately based on the abilities of students (Astalini, Kurniawan, Perdana, \& Pathoni 2019). It is necessary to pay attention to the learning model used in learning physics. Because some students view physics as a complex subject, but some view physics as a fun subject (Astuti 2015). Students who view physics as a fun subject will undoubtedly be interested in physics, and vice versa, students who view physics negatively will not be interested in physics subjects. For this reason, the learning model is expected to influence the ongoing teaching and learning process (Zakaria \& Ikhsan 2007).

Based on the results of interviews with physics teachers at SMA Negeri 3 Muaro Jambi on March 5,2020 , information was obtained that teachers tend to use the lecture model in the physics learning process. This model is used because of the lack of learning resources. In addition, due to the lack of students' interest in reading physics textbooks (Kurniawan, Perdana, \& Kurniasari, 2018). This makes teachers more likely to choose a lightweight model. This causes learning to be teacher-centered. This is undoubtedly less relevant to the current general conditions of education that demand technology. It is undeniable that even if we use technology, we can still observe Student Perceptions and an Interaction Effect Between Conceptual Gains and Attitudinal Profiles (Tsivitanidou, Georgiou, \& Ioannou 2021).

Teacher-centered learning, commonly referred to as conventional learning, is teacher-centered learning, not paying attention to the completeness of individual students (Kunandar 2011). This learning model tends to flow information in one direction, namely from teacher to student, so the lecture method is commonly used (Dewi, Asrial, \& Hariyadi 2015). Actually, in the teaching and learning process, the teacher plays a role in helping students solve problems to achieve the educational goals themselves (Sudana \& Mesnawa 2017).

Today, working in teams and networks is essential to solving complex problems. Therefore, collaborative learning methods have attracted much attention (Gašević 2019). Jigsaw is a collaborative learning method in which students take responsibility for a part of a task in predetermined small groups (Haftador, Shirazi, \& Mohebbi 2021). Each group member studies the problem in question, and then, members of various teams who have responsibility for the same part create a particular group and discuss the issue in question. After that, each member returned to their respective groups and taught the other members (Rachmawan, Suyitno, \& Agoestanto 2013). Since students make efforts and interact for a common goal, their motivation is increased compared to a competition-based setting. Abdullah assesses the jigsaw method as an effective way to increase students' academic motivation (Abdullah 2017). However, another study showed no increase in students' academic motivation using the jigsaw method. The description above shows that the Jigsaw cooperative learning model needs to be applied in physics subjects.

\section{METHODS}

This type of research is the type of research Mix method parallel-convergent type. According to Axinn \& Pearce (2006), Mixed method data collection strategies are explicitly designed to combine elements of one process. The point is that the mixed data collection strategy is a strategy that combines two techniques from a method. In this study, researchers combined qualitative and quantitative research.

For qualitative research, the technique used is interviews with interview sheet instruments. Meanwhile, for quantitative analysis, data was collected using a questionnaire instrument. According to Istijanto (2005), a questionnaire is a list of questions used by researchers to obtain data directly from sources. The questionnaire instrument that the researcher used as an instrument adapted from Devi Diyas Sari's thesis in 2012 by changing the name of the model used. The questionnaire uses a Likert scale. According to Much, Subroto, Farisa \& Haviana (2016), the Likert scale is a psychometric scale commonly used in questionnaires. The respondent's assessment is determined by the respondent's level of agreement with the question.

The alternative used by researchers for positive statements is the alternative strongly agree (SS) with point 5 , agree $(\mathrm{S})$ with point 4 , neutral $(\mathrm{N})$ with point 3 , disagree (TS) with point 2 , and strongly

e-Journal: http://doi.org/10.21009/1 
disagree with point 1 . As for the alternative negative statements, namely strongly agree (SS) with point 1 , agree (S) with point 2 , neutral $(\mathrm{N})$ with point 3 , disagree (TS) with point 4 , and strongly disagree with point 5 .

This research was conducted at SMA Negeri 3 Muaro Jambi. The sample of this study was taken by looking at and considering the average semester MID scores in physics learning. The number of samples in this study was 20 people. The analysis technique used for quantitative data is a descriptive statistical analysis using the SPSS 25 application. The steps for implementing the jigsaw cooperative learning model, according to Rachmawan, Suyitno \& Agoestanto (2013), are:

TABLE 1. Jigsaw Type Cooperative Learning Model Phase

\begin{tabular}{ll}
\hline Phase & \multicolumn{1}{c}{ Teacher activities } \\
\hline Phase 1 & Students are divided into several groups (each group consists of 5-6 students) \\
\hline Phase 2 & $\begin{array}{l}\text { The subject matter is given to students in the form of text which has been divided into } \\
\text { several sub-chapters }\end{array}$ \\
\hline Phase 3 & Each group member reads the sub-chapter assigned and is responsible for studying. \\
\hline Phase 4 & $\begin{array}{l}\text { Members of other groups who have studied the same subsection meet in expert groups to } \\
\text { discuss them. }\end{array}$ \\
\hline Phase 5 & $\begin{array}{l}\text { Each member of the expert group after returning to his group is in charge of teaching his } \\
\text { friends }\end{array}$ \\
\hline Phase 6 & $\begin{array}{l}\text { At home group meetings and discussions, students are billed in the form of individual } \\
\text { quizzes. }\end{array}$ \\
\hline
\end{tabular}

\section{RESULTS AND DISCUSSION}

The learning model will affect the teaching and learning process (Hadi \& Kasum 2015: 60). One of the learning models is the cooperative learning model. According to Rahman, Ahmar \& Rusli (2016: $425)$, in essence, the collaborative learning model places students into a team or group. The groups formed consist of four to six heterogeneous students (Majid 2014: 214). Each group member is expected to be able to work together because cooperation in learning is a positive attitude and can improve learning outcomes (Putri, Maison \& Darmaji 2018: 33).

The application of the cooperative learning model is carried out by maximizing teaching and learning activities employing cooperation and contribution of each group member (Pujiasri 2018: 2). One type of cooperative learning is the jigsaw type. According to Rusman (2013), in the jigsaw cooperative learning model, students are required to work together and mutually depend on each other positively among group members and be able to take responsibility independently.

The jigsaw type of cooperative learning model has advantages and disadvantages. As for Abdullah (2017), the benefits of this learning model are:

- Can foster a spirit of cooperation and enthusiasm for learning for students.

- Increase motivation, mutual respect between fellow students.

- Provide an opportunity to express ideas openly due to the limited number of students in each group.

- Train students to be able to communicate effectively.

Meanwhile, according to Isjoni (2011), the advantages of the cooperative jigsaw model are:

- In a cooperative classroom, students can interact with their peers and the teacher as a guide.

- Peer motivation can be used effectively to improve student cognitive learning and effective student growth.

- Cultivate student responsibility.

- $\quad$ Encourage active students and help each other in mastering the subject matter.

- To optimize the benefits of group learning.

Trisianawati, Djuddin \& Setiawan (2016), also suggest the advantages of the jigsaw cooperative learning model as follows:

- $\quad$ Students are more active, share opinions, and compete to achieve good results.

- $\quad$ Students have more opportunities to interact socially with their peers. 
- $\quad$ Students are more creative and have individual responsibility.

The drawbacks of the jigsaw type cooperative learning model, according to Abdullah (2017) are:

- The main principle of this learning model is learning by friends. This will be an obstacle because of differences in perceptions in understanding a concept discussed with other students. In this case, teacher supervision is needed so that mistakes do not occur

- It is challenging to convince students to be able to discuss conveying material to friends if students lack confidence

- $\quad$ Early use of this learning model is difficult to control, usually requires sufficient time and careful preparation before this learning occurs.

- The application of this learning model, when implemented in large classes (more than 40 students), is very difficult.

The results of the statistical analysis obtained regarding the response of students to the application of the jigsaw-type cooperative model in physics can be seen in the table below:

TABLE 2. The response of students in class X IPA 1 SMAN 3 Muaro Jambi to learning physics using the Jigsaw type cooperative learning model

\begin{tabular}{|c|c|c|c|c|c|c|c|}
\hline \multicolumn{4}{|c|}{ Characteristics } & \multirow{2}{*}{$\begin{array}{l}\text { the } \\
\text { mean }\end{array}$} & \multirow[b]{2}{*}{ median } & \multirow[b]{2}{*}{$\min$} & \multirow[b]{2}{*}{$\max$} \\
\hline interval & category & frequency & percent $(\%)$ & & & & \\
\hline $20.0-36.0$ & Not good & 0 & 0 & \multirow{5}{*}{67.05} & \multirow{5}{*}{66} & \multirow{5}{*}{60} & \multirow{5}{*}{79} \\
\hline $36.1-52.0$ & Not good & 0 & 0 & & & & \\
\hline $52.1-68.0$ & Pretty good & 13 & 65 & & & & \\
\hline $68.1-84.0$ & Well & 7 & 35 & & & & \\
\hline $84.1-100$ & Very good & 0 & 0 & & & & \\
\hline Total & & 20 & 100 & & & & \\
\hline
\end{tabular}

The responses given by students will affect the continuity of the learning process and affect the learning outcomes of students. In TABLE 2, the student's reactions to applying the jigsaw cooperative learning model in physics subject class X IPA II at SMA Negeri 3 Muaro Jambi are generally quite good, with an average consideration of 66 . The most dominant student response is quite good, equal to $65 \%$ (13 out of 20 students). The results of the interview below further support these results:

Question : is the jigsaw type cooperative learning model more functional and makes you skilled in learning physics?

Answer : This learning model is quite helpful and makes me skilled, but I wouldn't say I like it when moving groups

Question : does learning physics using the jigsaw cooperative learning model make you sleepy during the learning process?

Answer : no. Because if I'm sleepy, I'll be confused when the group has changed positions.

Question : does learning physics using a cooperative learning model motivate you?

Answer : yes. But occasionally I feel lazy because I have to change seats.

Furthermore, 35\% (7 of 20 students) responded to the application of the jigsaw cooperative learning model in physics subjects well. The following interview results support these results:

Question : is the jigsaw type cooperative learning model more functional and makes you skilled in learning physics?

Answer : Of course, implementing this type of jigsaw cooperative learning model makes the classroom atmosphere come alive. It made me feel that learning physics was fun.

Question : does learning physics using the jigsaw cooperative learning model make you sleepy during the learning process? 
Answer : no. Because I like the way of learning using the jigsaw type of cooperative learning model.

Question : does learning physics using the jigsaw cooperative learning model make you more motivated?

Answer : yes. I wanted to understand the learning material better to discuss it with my friends.

Based on the results of descriptive statistics and the answers given by students when interviewed, it appears that there are still many students who respond to the application of the jigsaw-type cooperative learning model in physics learning quite well. And there are no students who respond less or worse to applying the jigsaw type cooperative learning model in physics subjects. The negative comments include students feeling lazy in moving from one group to another. This laziness can be overcome by such as parents' motivation, comfortable learning environment, improvement in worship, and supportive learning colleagues (Rachim 2020)

Various students' responses to the application of the jigsaw cooperative learning model. According to Sobur (2003), in general, 2 factors affect individual learning, namely:

- Endogenous factors, also called internal factors, are all factors within the individual.

- Exogenous factors are often referred to as external factors, namely all factors outside the individual, such as parents or environmental conditions around the individual.

In addition, from the question and answer, it was also known that the jigsaw model increased student learning motivation, in line with the results of similar research (Haftador, Shirazi, \& Mohebbi 2021). and keep in mind that teachers need high creativity or the courage to do trial and error in producing positive changes from their assignments. Teachers are brave and able to innovate in carrying out their functions. The key to the success of innovation lies in the willingness to experiment, including in varying the learning model in the classroom (Farhan 2021).

\section{CONCLUSION}

From the research results, applying the type of jigsaw cooperative learning model in physics subjects received various responses from students. The results showed 65\% (13 of 20 students) responded quite well, and 35\% (7 of 20 students) responded well to applying the jigsaw cooperative learning model in physics subjects. The use of learning models needs more attention. Because it will affect the sustainability and learning outcomes of students. Suggestions for the school are to innovate the models used in both physics and other subjects.

\section{ACKNOWLEDGMENT}

We acknowledge to SMAN 3 Muaro Jambi for allowing us to retrieve data at SMAN 3 Muaro Jambi. We would also like to thank the respondents and those who helped make this article.

\section{REFERENCES}

Abdullah, R 2017, 'Pengaruh Penerapan Model Pembelajaran Kooperatif Tipe Jigsaw Pada Mata Pelajaran Kimia Di Madrasah Aliyah', Lantanida Journal, vol. 5, no.1, pp. 13-28.

Astalini, A, Kurniawan, DA \& Sumaryanti, S 2018, 'Sikap siswa terhadap pelajaran fisika di sman kabupaten Batanghari', JIPF (Jurnal Ilmu Pendidikan Fisika), vol. 3, no. 2, pp. 59-64.

Astalini, A, Kurniawan, DA, Perdana, R \& Pathoni, H 2019, 'Identifikasi Sikap Peserta Didik terhadap Mata Pelajaran Fisika di Sekolah Menengah Atas Negeri 5 Kota Jambi', UPEJ Unnes Physics Education Journal, vol. 8, no. 1, pp. 34-43.

Astuti, SP 2015, 'Pengaruh kemampuan awal dan minat belajar terhadap prestasi belajar fisika', Formatif: Jurnal Ilmiah Pendidikan MIPA, vol. 5, no. 1. 
Axinn, WG \& Pearce, LD 2006, 'Mixed-Method Data Collection Strategie', United States of America: Cambridge University Pres.

Devi, DS 2012, 'Penerapan Model Problem Based Learning (PBL) Untuk Meningkatkan Kemampuan Berpikir Kritis Peserta Didik Pada Pembelajaran IPA Kelas VIII SMP Negeri 5 Sleman’.

Dewi, RK, Asrial, A \& Hariyadi, B 2015, 'Pengaruh Penggunaan Model Pembelajaran Group Investigasi Bermedia dan Motivasi Belajar Siswa terhadap Pemahaman Konsep Biologi', EduSains: Jurnal Pendidikan Matematika dan Ilmu Pengetahuan Alam Universitas Jember, vol. 4, no. 1.

Farhan, A, Herliana, F, Evendi, E, Devy, NK \& Mauliza, F 2021 'The Implementation of 'Guru Penggerak' (Organizer Teachers) Concept to Innovation of The Discussion Methods in Thermodynamics Course', Jurnal Penelitian \& Pengembangan Pendidikan Fisika, vol. 7, no. 1, pp. $1-12$.

Gašević D, Joksimović S, Eagan BR, \& Shaffer DW 2019 'SENS: network analytics to combine social and cognitive perspectives of collaborative learning', Comput Hum Behav. vol. 92, pp. 562-577.

Hadi, S \& Kasum, MU 2015, 'Pemahaman konsep matematika siswa SMP melalui penerapan model pembelajaran kooperatif tipe memeriksa berpasangan (Pair Checks)', EDU-MAT: Jurnal Pendidikan Matematika, vol. 3, no. 1.

Haftador, AM, Shirazi, F \& Mohebbi, Z 2021 'Online class or flipped-jigsaw learning? Which one promotes academic motivation during the COVID-19 pandemic?' BMC Med Educ, vol. 21, pp. 499

Isjoni 2011, 'Cooperative Learning Efektivitas Pembelajaran Kelompok', Bandung: Alfabeta.

Istijanto 2005, 'Riset Sumber Daya Manusia, Cara Praktis Mendeteksi Dimensi- Dimensi Kerja karyawan', PT. Gramedia Pustaka Utama, Jakarta.

Kunandar 2011, 'Guru Profesional Implementasi Kurikulum Tingkat Satuan Pendidikan (KTSP) dan Sukses dalam Sertifikasi Guru’, Rajawali Pers, Jakarta.

Kurniawan, DA, Perdana, R \& Kurniasari, D 2018, 'Identification of Student Attitudes toward Physics Learning at Batanghari District High School', The Educational Review, USA, vol. 2, no. 9, pp. 475484.

Majid, A 2014, 'Strategi Pembelajaran. Bandung: Remaja Rosdakarya'.

Much, I, Subroto, I, Farisa, S \& Haviana, C 2016, 'Sistem Informasi Angket Pengukuran Skala Kebutuhan Materi Pembelajaran Tambahan Sebagai Pendukung Pengambilan Keputusan Di Sekolah Menengah Atas Menggunakan Skala Likert', vol. 1, no. 2, pp. 1-12.

Mustamiin, MZ 2016, 'Pengaruh Penggunaan Model Kooperatif Learning Tipe Jigsaw Terhadap Hasil Belajar IPS Di Tinjau Dari Motivasi Berpretasi', Jurnal Teknologi Pendidikan: Jurnal Penelitian dan Pengembangan Pembelajaran, vol. 1, no. 2, pp. 65-76.

Pujiasri, D 2018, 'Tanggapan Peserta Didik Terhadap Model Pembelajaran Kooperatif Teknik Jigsaw Pada Permainan Bola Besar', Pendidikan Jasmani Kesehatan dan Rekreasi, vol. 7, no. 5.

Putri, AR, Maison, M \& Darmaji, D, 2018, 'Kerjasama Dan Kekompakan Siswa Dalam Pembelajaran Fisika Di Kelas Xi Mipa Sma Negeri 3 Kota Jambi’, EduFisika: Jurnal Pendidikan Fisika, vol. 3, no. 2, pp. 32-40.

Rachim, DK N 2020 'Study of The Lazy Nature of Physics Students Using The Quadratic Optimal Control Method', Jurnal Penelitian \& Pengembangan Pendidikan Fisika, vol. 6, no. 2, pp. 279 288.

Rachmawan, S, Suyitno, H \& Agoestanto, A 2013, 'Penerapan Jigsaw II dan Student Teams Achievement Divisions Berbantuan Alat Peraga', Kreano, Jurnal Matematika Kreatif-Inovatif, vol. 4, no. 1, pp. 26-33. 
Rahman, A, Ahmar, A \& Rusli, R. 2016, 'The influence of cooperative learning models on learning outcomes based on students learning styles', World Transactions on Engineering and Technology Education, vol. 14, no. 3 .

Rusman 2013, 'Model-model Pembelajaran', Bandung: Media Mandiri Pers.

Sobur, Alex 2003, 'Psikologi Umum', Bandung: Pustaka Setia.

Sudana, IPA \& Wesnawa, IGA 2017, 'Penerapan Model Pembelajaran Kooperatif Tipe STAD Untuk Meningkatkan Hasil Belajar IPA', Jurnal Ilmiah Sekolah Dasar, vol. 1, no. 1, pp. 1-8.

Trisianawati, E, Djudin, T \& Setiawan, R 2016, 'Pengaruh model pembelajaran kooperatif tipe jigsaw terhadap hasil belajar siswa pada materi v'ektor di kelas X SMA Negeri 1 Sanggau Ledo', Jurnal Penelitian Fisika dan Aplikasinya (JPFA), vol. 6, no. 2, pp. 51-60.

Tsivitanidou, OE, Georgiou, Y \& Ioannou A 2021 'A Learning Experience in Inquiry-Based Physics with Immersive Virtual Reality: Student Perceptions and an Interaction Effect Between Conceptual Gains and Attitudinal Profiles', J Sci Educ Technol, vol. 30, pp. 841-861.

Vanslambrouck, S, Zhu, C, Lombaerts, K, Philipsen, B, \& Tondeur J 2018 'Students' motivation and subjective task value of participating in online and blended learning environments' Internet High Educ, vol. 36, pp. 33-40.

Zakaria, E and Iksan, Z 2007, 'Promoting Cooperative Learning in Science and Mathematics Education: A Malaysian Perspective', Eurasia Journal of Mathematics, Science \& Technology Education, vol. 3, no. 1 Tahun 2007. pp. 35-39. 
